Acta medico-historica Rigensia (1992) I: 321-323

DOI: 10.25143/amhr.1992.I.25

\title{
НИНА ФЕДОРОВНА СТРАДЫНЬ
}

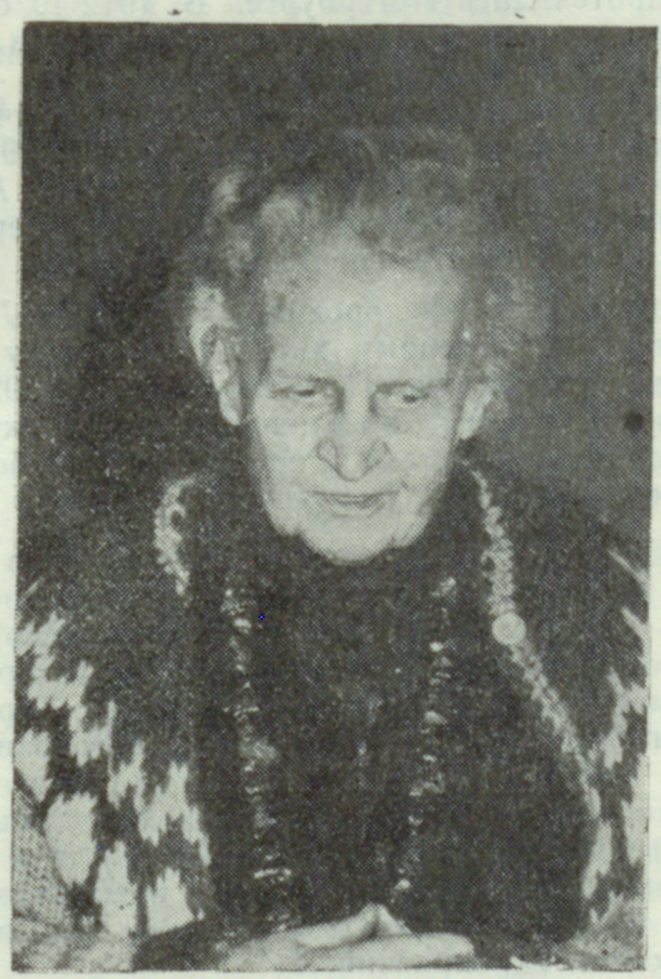

После продолжительной болезни 15 июня 1991 г. скончалась старейший врач Латвии Нина Федоровна Страдынь, известный специалист по физиотерапии. Ее жизнь тесно связана с развитием медицины Латвии как в довоенный, так и послевоенный период. Пользуясь заслуженным авторитетом и уважением среди медицинской общественности, 16 сентября 1988 г. при восстановлении Лат- 
вийского общества врачей она эстафету из рук старшего поколения передала молодым коллегам.

Нина Федоровна родилась 1 февраля 1887 г. в г. Астрахань. Ее отец Ф. С. Малышев был директором ВолгоКамского банка, известным библиофилом и коллекционером, а мать Е. А. Смирнова происходила из нижнегородской купеческой семьи. Детство и юность Нины Федоровны протекали в Петербурге. В 1912 г. она окончила Ивановскую частную женскую гимназию, а в 1921 г. Петроградский Женский мединститут (ныне - 1-й Ленинградский мединститут). Во время учебы участвовала в кампаниях против голода и эпидемий. С 1921 по 1924 г. Нина Федоровна работала у профессора С. А. Бруштейна в Петроградском институте физической терапии, где и освоила свою будущую специальность.

В 1924 г. Нина Федоровна переехала в Латвию к своему мужу - известному хирургу, онкологу и историку медицины профессору П. Страдыню, в 1928 г. повторно сдала выпускные экзамены при медфакультете Латвийского университета и в дальнейшем работала в Риге врачом-физиотерапевтом и рентгенологом.

В 1939 г. Нина Федоровна создала и до 1944 г. заведовала кабинетом физиотерапии при раковой больнице (ныне - Рижский городской онкодиспансер). С 1945 по 1974 г. она заведовала отделением физиотерапии Республиканской клиничсской больницы им. П. Страдыня, оставив заметный вклад в его совершенствовании. Одновременно с 1944 по 1950 г. она являлась рентгенологом Республиканской костно-туберкулезной больницы и ассистентом кафедры рентгенологии медфакультета Латвийского университета. Занималась также преподаванием физиотерапии во 2-м рижском медицинском училище и при Базе курсовых мероприятий.

В 1952 г. Нина Федоровна - сооснователь Латвийского Научного общеетва курортологов и физиотерапевтов, потом долголетний член его правления, в 1971 г. избрана почетным членом Всесоюзного научного общества курортологов и физиотерапевтов, а в 1988 г. в связи с 150-летием курорта Кемери награждена памятной медалью А. А. Лозинского.

Нина Федоровна - автор около 20 научных публика- 
ций в области физиотерапий, рентгенологий, курортологии и истории медицины. Она значительно способствовала становлению Музея истории медицины им. П. Страдыня, с 1958 г. являлась постоянным членом ученого совета музея, в 1986 г. удостоена награды им. П. Страдыня. В последние годы жизни, находясь уже на пенсии, активно участвовала в общественной деятельности.

Нина Федоровна - мать четырех детей.

Похоронена на Лесном кладбище в Риге.

Светлая память о Нине Федоровне навсегда сохранится у медицинской общественности Латвия. 